\title{
DOSE OF TRINEXAPAC-ETHYL AND THE AGE OF SEEDLING INFLUENGE THE STIMULATORY EFFECT IN EUCALYPTUS
}

\author{
da Silveira MRF, Bacha AL*, Braga AF, Carrega WC \& da Costa Aguiar Alves PL \\ Sao Paulo State University - UNESP/FCAV, Department of Biology Applied to Agriculture, 14884900 Jaboticabal - SP, \\ Brazil.
}

*allan_lb@hotmail.com

Submitted March 2020; accepted September 2020

\begin{abstract}
Trinexapac-ethyl (TE) has recently been shown to have a stimulatory effect on the initial growth of Eucalyptus seedlings. However, the optimal dose and seedling age at which TE should be applied has not been assessed. The objective of our study was to evaluate the effects of sub-doses of TE on the initial growth of eight Eucalyptus clones. The experiment was conducted in an open area. The treatments were arranged in an $8 \times$ 3 factorial scheme, meaning eight Eucalyptus clones and three doses of TE $\left(0,15\right.$ and $\left.30 \mathrm{~g}^{\text {a.i. }} \mathrm{ha}^{-1}\right)$ sprayed at 70 days after planting. Plant height, stem diameter, shoot and root dry mass, and leaf area were evaluated. Eucalyptus clones differed in their growth regardless TE application. TE did not negatively affect the growth of any clones but doses used in our study were not sufficient to give a significant positive effect on growth when applied at 70 days after planting. We suggest that older Eucalyptus seedlings need higher doses of TE to reveal potential stimulatory effects on growth of the plants.
\end{abstract}

Keywords: Plant growth regulator, gibberellins, chemical ripener, Eucalyptus clones.

\section{INTRODUCTION}

The forestry sector is of significant importance to Brazil's economy. Forestry accounted for $1.2 \%$ of the national GDP and contributed over $\mathrm{R} \$ 69$ billion in 2015. Of the 7.8 million ha of forest planted in Brazil for economic purposes, more than $70 \%$ were Eucalyptus (Ibá 2016). The large increase in Eucalyptus plantations has been attributed to improved silvicultural practices and breeding programme. The market launch of several outstanding clones has made Brazil's Eucalyptus plantations the most productive in the world (Ibá 2016). Clones available on the market are of the Eucalyptus urograndis hybrid (E. urophylla $\times$ E. grandis), developed for fast growth, disease resistance and drought tolerance (Retief \& Stanger 2009). However, such growth was only possible because of the cultural practices improvement as well as the development of breeding programme. Thus, several clones were launched in the market, enabling the country to obtain the highest Eucalyptus productivity in the world (Stape et al. 2004, Pereira et al. 2012, Ibá 2016).

Biotic (e.g. competition and herbivory) and abiotic (e.g. water and nutrient deficiencies) stressors can retard the growth of newly planted Eucalyptus seedlings in the field (Nambiar \& Sands
1993, Garau et al. 2008). As growth disruptions during this critical period of development may result in productivity losses (Sankaran et al. 2004, Garau et al. 2009), a number of studies have focused on boosting seedling growth.

Application of trinexapac-ethyl (TE) to E. urograndis clones gave total dry mass gains of up to $60 \%$ in Clone 1407 (Bacha et al. 2017). The positive effect resulting from small-dose applications of a chemical that would otherwise be toxic in high quantities is known as hormesis (Calabrese \& Baldwin 2002). This phenomenon has been observed previously for several plant species (coffee, pine, corn and soybean), including Eucalyptus (Velini et al. 2008, Carvalho et al. 2013, Pereira et al. 2013, Bacha et al. 2018) .

$\mathrm{TE}$ is a plant growth regulator that acts in the final stages of gibberellic acid biosynthesis (Rademacher 2000). It is often used in sugarcane to accelerate the maturation process and schedule the harvest (Nascimento et al. 2009) and in other monocotyledonous crops, such as rice and wheat, to avoid lodging (Moddus 2020). At the molecular level, TE inhibits the conversion of $\mathrm{GA}_{20}$ to $\mathrm{GA}_{1}$ (a major bioactive gibberellin) by deactivating the enzyme $\mathrm{GA}_{20}$ $3 \beta$-hydroxylase. TE competes with 2-oxogluteate 
for the metabolic substrate $\mathrm{Fe}^{+2} /$ ascorbatedependent dioxygenase (Adams et al. 1992, Rademacher 2016, Hedden 2016).

For Eucalyptus, applying $15 \mathrm{~g}$ a.i. ha ${ }^{-1}$ of TE before field-planting seedlings increased stem diameter by up to $17 \%$ (Pires et al. 2013). Similarly, a pre-planting TE application of $60 \mathrm{~g}$ a.i. ha ${ }^{-1}$ gave gains of $30 \%$ in stem dry mass (Bacha et al. 2017). When applied at $200 \mathrm{~g}$ a.i. ha $^{-1} 46$ days after planting, a 29\% increase in crown diameter over untreated seedlings was recorded (Correia \& Villela 2015). In phosphorus deficient conditions, $30 \mathrm{~g}$ a.i. $\mathrm{ha}^{-1}$ applied to E. urograndis (Clone I-144) at 33 days after planting yielded a $19 \%$ increase in leaf area (Bacha et al. 2018). While these studies have shown that TE has a stimulatory effect on the initial growth of Eucalyptus seedlings, more studies on optimal dosage and timing of application are needed. Studies assessing the growth response to TE of the many Eucalyptus clones that are available on the market, are needed as baseline information for breeding programs. The present study evaluates the effect of TE on the initial growth of eight $E$. urograndis clones.

\section{MATERIALS AND METHODS}

The potted trial was conducted in an open area, in the municipality of Jaboticabal-SP $\left(21^{\circ} 14^{\prime} \mathrm{S}\right.$ and $48^{\circ} 17^{\prime} \mathrm{W}$ ) in Brazil, from January to May 2014. Mean air temperature was $23.7^{\circ} \mathrm{C}$ (range $\left.=18.4-30.8{ }^{\circ} \mathrm{C}\right)$, relative humidity $(\mathrm{RH})$ was $71.6 \%$ and insolation of 249 hours per month was recorded (Table 1).

Seedlings of eight commercial E. urograndis clones were planted in $10 \mathrm{~L}$ plastic pots filled with Dark Red Latosol topsoil and sand $(2: 1 \mathrm{v} / \mathrm{v})$. The clones were 3203 (designated here as Clone 1), 3487 (Clone 2), I-144 (Clone 3), 3334 (Clone 4), 1407 (Clone 5), 2361 (Clone 6), I-224 (Clone 7) and GG100 (Clone 8). Seedlings had a mean height and stem diameter of $33 \mathrm{~cm}$ and $2.8 \mathrm{~mm}$ respectively, and about 10 leaves. A one-time application of NPK 4-14-18 fertilizer was given at a rate of $300 \mathrm{~kg} \mathrm{ha}^{-1}$, and the experiment was conducted without water restriction. At 70 days after planting, seedlings were sprayed with TE at doses of 0,15 and $30 \mathrm{~g}$ a.i. ha ${ }^{-1}$. A $\mathrm{CO}_{2}$-pressurised backpack sprayer equipped with a double rod spray and adjusted for a tank volume of $200 \mathrm{~L} \mathrm{ha}^{-1}$ was used. The application took place in a spray room with an ambient temperature of $29^{\circ} \mathrm{C}$ and $\mathrm{RH}$ of $70 \%$. A randomised complete block design was used, and the treatments consisted of a factorial scheme $8 \times 3$, meaning eight clones and three doses of TE, with four replicates.

At 7, 14, 21, 28 and 35 days after application, plant height was measured (from stem base to apical bud) with a ruler (in $\mathrm{mm}$ ) and stem diameter was measured with a digital callipers (at $1 \mathrm{~cm}$ from stem base). At the end of the experiment, 42 days after application, the plants were cut at the stem base and the leaves detached for determination of total leaf area using a leaf area meter.

To obtain shoot dry matter and root dry matter stems, leaves and roots were separated, then dried in a forced-air convection oven at $70{ }^{\circ} \mathrm{C}$ for 96 hours until constant mass of the samples was achieved. The samples were then individually weighed. Absolute Growth Rates (AGR) for the plants were calculated using

Table 1 Meteorological data from the region of the city of Jaboticabal-SP in Brazil, during the experiment months in 2014

\begin{tabular}{lccccccccc}
\hline Month & $\begin{array}{c}\mathrm{P} \\
(\mathrm{hPa})\end{array}$ & $\begin{array}{c}\mathrm{T}_{\max } \\
\left({ }^{\circ} \mathrm{C}\right)\end{array}$ & $\begin{array}{c}\mathrm{T}_{\min } \\
\left({ }^{\circ} \mathrm{C}\right)\end{array}$ & $\begin{array}{c}\mathrm{T}_{\text {ave }} \\
\left({ }^{\circ} \mathrm{C}\right)\end{array}$ & $\begin{array}{c}\mathrm{RH} \\
(\%)\end{array}$ & $\begin{array}{c}\text { Precipitation } \\
(\mathrm{mm})\end{array}$ & $\begin{array}{c}\text { NRD } \\
\text { Insolation } \\
(\mathrm{h})\end{array}$ \\
\hline Jan & 943.8 & 32.6 & 19.9 & 25.5 & 69.1 & 99.8 & 13 & 294.1 \\
Feb & 943.0 & 32.5 & 19.9 & 25.5 & 67.0 & 83.0 & 12 & 233.9 \\
Mar & 943.6 & 30.9 & 19.5 & 24.1 & 76.8 & 106.8 & 10 & 238.4 \\
Apr & 944.4 & 30.1 & 17.9 & 23.0 & 75.2 & 63.3 & 8 & 241.2 \\
May & 945.4 & 28.0 & 14.6 & 20.2 & 70.0 & 6.7 & 4 & 237.4 \\
Year 2014 (averange) & 944.7 & 30.8 & 17.3 & 23.1 & 66.5 & 814.6 & 95 & 2861.3 \\
\hline
\end{tabular}

$\mathrm{RH}=$ relative air humidity, $\mathrm{NRD}=$ number of rainy days, $\mathrm{T}_{\max }=$ maximum temperature, $\mathrm{T}_{\min }=$ minimum temperature, $\mathrm{T}_{\text {ave }}=$ average temperature, $\mathrm{P}=$ atmospheric pressure 
the formula proposed by Benincasa (2003) (equation 1).

$$
\mathrm{AGR}=\mathrm{W}_{\mathrm{t}}-\mathrm{W}_{\mathrm{o}} / \mathrm{T}
$$

where $\mathrm{W}_{\mathrm{t}}$ and $\mathrm{W}_{\mathrm{o}}=$ the final and initial values, respectively, of the assessed variable and $\mathrm{T}=$ total observation period.

The data were subjected to analysis of variance by the F-test and the means were compared by the Tukey's test at the $5 \%$ level of probability. Statistical analysis was performed using AgroEstat software (version 1.1.0.626) (Barbosa \& Maldonado 2011).

\section{RESULTS}

From 7 to 35 days after TE application, no significant effect of the interactions between clones and doses on plant height was observed (Table 2). At 7 days after application, Clone 1 plants were still taller than plants of Clones 3, 5 and 6 , which in turn were taller than Clone 2, 7, 4 and 8 plants. The last two clones presented lower height (Table 2), thus maintaining the same behaviour observed at 0 days after application. These clone heights were consistent up to 35 days after application, at which point Clone 1 was 132\% taller than Clones 2 and 8.

Averaged across TE dosages, height absolute growth rate of Clone 1 was greatest at $0.55 \mathrm{~cm} \mathrm{day}^{-1}$, followed by $0.52 \mathrm{~cm} \mathrm{day}^{-1}$ for Clone 6 while the remaining clones was $0.46 \mathrm{~cm}^{\text {day }^{-1}}$ on average (Table 3). Height absolute growth rate of Clone 8 at $0.36 \mathrm{~cm} \mathrm{day}^{-1}$ was lowest of all the clones.

Stem diameter of Clone 8 at the time of application was smaller than that of the other clones (Figure 1) but from 7 days after application onward Clone 8 stem diameter was not significantly smaller than that of the other clones (Table 4). It is noted that at 21 days after application, stem diameters (averaged across all clones) for plants receiving 15 and $30 \mathrm{~g}$ a.i. ha ${ }^{-1}$, were significantly different, while not differing from the untreated control. This response was not observed during the remainder of the experimental period (Table 4).

Table 2 Height of eight Eucalyptus urograndis clones at 7, 14, 21, 28 \& 35 days after application (DAA) of trinexapac-ethyl

\begin{tabular}{|c|c|c|c|c|c|}
\hline \multirow{2}{*}{ Clones } & \multicolumn{5}{|c|}{ Height $(\mathrm{cm})$} \\
\hline & 7 DAA & $14 \mathrm{DAA}$ & $21 \mathrm{DAA}$ & 28 DAA & 35 DAA \\
\hline (1) - 3203 & $72.33 \mathrm{a}$ & $77.58 \mathrm{a}$ & $81.12 \mathrm{a}$ & $84.58 \mathrm{a}$ & $86.62 \mathrm{a}$ \\
\hline (2) -3487 & $57.33 d$ & $60.75 \mathrm{~d}$ & $62.92 \mathrm{de}$ & $65.17 \mathrm{~cd}$ & $67.04 \mathrm{de}$ \\
\hline (3) - I-144 & $65.58 \mathrm{~b}$ & $68.91 b$ & $71.17 \mathrm{bc}$ & $73.42 b$ & $76.17 \mathrm{~b}$ \\
\hline (4) - 3334 & $59.33 \mathrm{~cd}$ & $63.33 \mathrm{~cd}$ & $65.92 \mathrm{~cd}$ & $68.33 \mathrm{bc}$ & $69.67 \mathrm{cde}$ \\
\hline (5) - 1407 & $62.83 \mathrm{bc}$ & $67.50 \mathrm{bc}$ & $70.25 \mathrm{bc}$ & $72.25 \mathrm{~b}$ & $74.80 \mathrm{bc}$ \\
\hline (6) - 2361 & $63.75 \mathrm{bc}$ & $68.33 \mathrm{bc}$ & $72.00 \mathrm{~b}$ & $73.50 \mathrm{~b}$ & $75.67 \mathrm{bc}$ \\
\hline (7) - I-224 & $60.08 \mathrm{~cd}$ & $63.50 \mathrm{~cd}$ & $66.25 \mathrm{~cd}$ & $67.80 \mathrm{bcd}$ & $70.00 \mathrm{~cd}$ \\
\hline (8) - GG100 & $55.41 d$ & $58.17 \mathrm{~d}$ & $60.25 \mathrm{e}$ & $62.20 \mathrm{~d}$ & $63.87 \mathrm{e}$ \\
\hline \multicolumn{6}{|l|}{ Trinexapac-ethyl } \\
\hline D1 (15 g a.i. ha-1) & $62.90 \mathrm{a}$ & $66.71 \mathrm{a}$ & $69.16 \mathrm{a}$ & $71.39 \mathrm{a}$ & $73.89 \mathrm{a}$ \\
\hline D2 (30 g a.i. ha-1) & $60.90 \mathrm{a}$ & $65.15 \mathrm{a}$ & $67.90 \mathrm{a}$ & $70.23 \mathrm{a}$ & $72.26 \mathrm{a}$ \\
\hline D3 (0 g a.i. ha $\left.{ }^{-1}\right)$ & $62.71 \mathrm{a}$ & $66.15 \mathrm{a}$ & $69.14 \mathrm{a}$ & $71.09 \mathrm{a}$ & $72.78 \mathrm{a}$ \\
\hline F clones $(\mathrm{C})$ & $21.43^{* *}$ & $24.10^{* *}$ & $27.74^{* *}$ & $27.75^{* *}$ & $26.70^{* *}$ \\
\hline F doses (D) & $2.09^{\mathrm{ns}}$ & $1.11^{\mathrm{ns}}$ & $0.91^{\mathrm{ns}}$ & $0.57^{\mathrm{ns}}$ & $1.00^{\mathrm{ns}}$ \\
\hline $\mathrm{F} \mathrm{C} \times \mathrm{D}$ & $1.34^{\mathrm{ns}}$ & $1.30^{\mathrm{ns}}$ & $0.90^{\mathrm{ns}}$ & $0.85^{\mathrm{ns}}$ & $1.17^{\mathrm{ns}}$ \\
\hline CV (\%) & 6.43 & 6.42 & 6.18 & 6.34 & 6.45 \\
\hline
\end{tabular}

Means followed by the same letter in the same column do not differ from each other by Tukey's test at $5 \%$ probability; ${ }^{n s}=$ not significant, ${ }^{* *}=$ significant at $1 \%$ probability by the F-test; $\mathrm{CV}=$ coefficient of variation 
Table 3 Absolute growth rate (AGR) of eight Eucalyptus urograndis clones from 0 to 35 days after application of trinexapac-ethyl

\begin{tabular}{lcccccccc}
\hline \multirow{2}{*}{ AGR } & \multicolumn{8}{c}{ Clone } \\
\cline { 2 - 10 } & 1 & 2 & 3 & 4 & 5 & 6 & 7 & 8 \\
\hline Height $\left(\mathrm{cm} \mathrm{day}^{-1}\right)$ & 0.55 & 0.43 & 0.47 & 0.47 & 0.49 & 0.52 & 0.47 & 0.36 \\
Diameter $\left(\mathrm{mm} \mathrm{day}^{-1}\right)$ & 0.061 & 0.082 & 0.071 & 0.067 & 0.066 & 0.077 & 0.091 & 0.084 \\
\hline
\end{tabular}

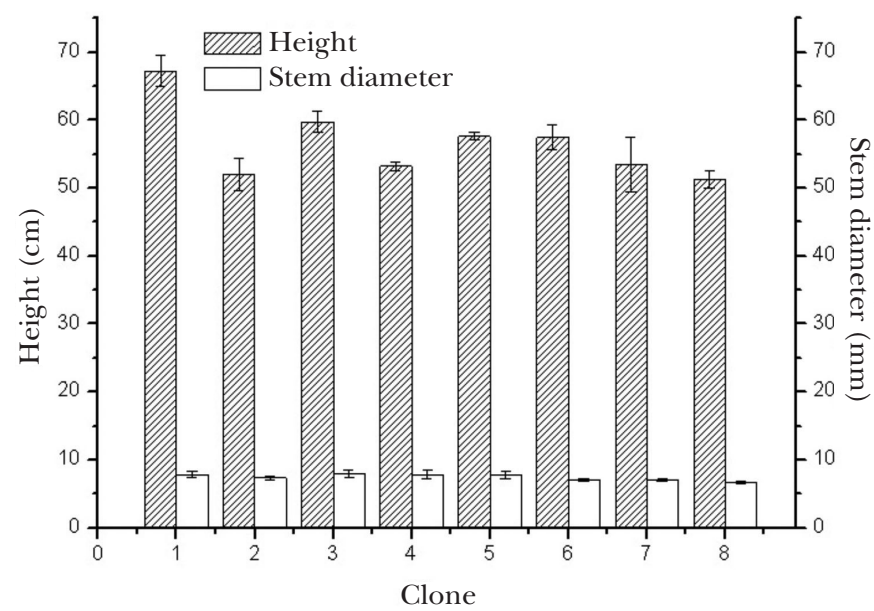

Figure 1 Height and stem diameter of eight Eucalyptus urograndis clones at 70 days after planting with the application of trinexapac-ethyl

Table 4 Stem diameter of eight Eucalyptus urograndis clones at 7, 14, 21, 28 \& 35 days after application (DAA) of trinexapac-ethyl

\begin{tabular}{lccccc}
\hline \multirow{2}{*}{ Clones } & \multicolumn{5}{c}{ Stem diameter $(\mathrm{mm})$} \\
\cline { 2 - 6 }$(1)-3203$ & $7.94 \mathrm{DA}$ & $8.42 \mathrm{a}$ & $8.90 \mathrm{a}$ & $9.33 \mathrm{a}$ & $9.98 \mathrm{a}$ \\
$(2)-3487$ & $8.01 \mathrm{a}$ & $8.72 \mathrm{a}$ & $9.10 \mathrm{a}$ & $9.54 \mathrm{a}$ & $10.17 \mathrm{a}$ \\
$(3)-\mathrm{I}-144$ & $8.19 \mathrm{a}$ & $8.83 \mathrm{a}$ & $9.12 \mathrm{a}$ & $9.73 \mathrm{a}$ & $10.47 \mathrm{a}$ \\
$(4)-3334$ & $8.00 \mathrm{a}$ & $8.64 \mathrm{a}$ & $8.99 \mathrm{a}$ & $9.53 \mathrm{a}$ & $10.16 \mathrm{a}$ \\
$(5)-1407$ & $8.18 \mathrm{a}$ & $8.76 \mathrm{a}$ & $9.27 \mathrm{a}$ & $9.73 \mathrm{a}$ & $10.07 \mathrm{a}$ \\
$(6)-2361$ & $7.64 \mathrm{a}$ & $8.44 \mathrm{a}$ & $8.80 \mathrm{a}$ & $9.23 \mathrm{a}$ & $9.77 \mathrm{a}$ \\
$(7)-$ I-224 & $8.11 \mathrm{a}$ & $8.90 \mathrm{a}$ & $9.34 \mathrm{a}$ & $9.71 \mathrm{a}$ & $10.24 \mathrm{a}$ \\
$(8)-$ GG100 & $7.58 \mathrm{a}$ & $8.30 \mathrm{a}$ & $8.77 \mathrm{a}$ & $9.10 \mathrm{a}$ & $9.61 \mathrm{a}$ \\
\hline Trinexapac-ethyl & & & & \\
\hline D1 $\left(15\right.$ g a.i. ha $\left.{ }^{-1}\right)$ & $8.03 \mathrm{a}$ & $8.75 \mathrm{a}$ & $9.24 \mathrm{a}$ & $9.70 \mathrm{a}$ & $10.25 \mathrm{a}$ \\
D2 $\left(30\right.$ g a.i. ha $\left.{ }^{-1}\right)$ & $7.77 \mathrm{a}$ & $8.53 \mathrm{a}$ & $8.81 \mathrm{~b}$ & $9.25 \mathrm{a}$ & $9.90 \mathrm{a}$ \\
D3 $\left(0\right.$ g a.i. ha $\left.{ }^{-1}\right)$ & $7.80 \mathrm{a}$ & $8.60 \mathrm{a}$ & $9.10 \mathrm{ab}$ & $9.50 \mathrm{a}$ & $10.02 \mathrm{a}$ \\
F clones $(\mathrm{C})$ & $2.95^{\mathrm{ns}}$ & $1.53^{\mathrm{ns}}$ & $1.56^{\mathrm{ns}}$ & $1.37^{\mathrm{ns}}$ & $1.44^{\mathrm{ns}}$ \\
F doses $(\mathrm{D})$ & $1.50^{\mathrm{ns}}$ & $1.14^{\mathrm{ns}}$ & $4.09^{*}$ & $3.08^{\mathrm{ns}}$ & $4.90^{\mathrm{ns}}$ \\
F C $\times$ D & $0.93^{\mathrm{ns}}$ & $0.79^{\mathrm{ns}}$ & $1.04^{\mathrm{ns}}$ & $0.62^{\mathrm{ns}}$ & $1.48^{\mathrm{ns}}$ \\
CV $(\%)$ & 8.38 & 7.02 & 6.63 & 7.03 & 6.81 \\
\hline
\end{tabular}

Means followed by the same letter in the column do not differ from each other by Tukey's test at $5 \%$ probability; ${ }^{\text {ns }}=$ not significant $;{ }^{*}=$ significant at $5 \%$ probability by the F-test; $\mathrm{CV}=$ coefficient of variation 
Stem diameter absolute growth rate was highest in Clones 7, 8 and 2 with values of 0.091, 0.084 and $0.082 \mathrm{~mm} \mathrm{day}^{-1}$, respectively followed by Clones 6 and 4 at 0.077 and $0.067 \mathrm{~mm} \mathrm{day}^{-1}$, respectively (Table 3 ).

Clones differed in shoot and root growth as seen in shoot dry matter, root dry matter and leaf area (Table 5). Shoot dry matter (averaged across TE doses) of Clones 6 and 7 was greater than that of Clones 3 and 4, while the others presented intermediate behaviour, independently of TE doses (Table 5). The two highest root dry matter values were from Clones 1 and 6 (18.3 and $18.5 \mathrm{~g}$, respectively), significantly higher than that of Clone $4(15.2 \mathrm{~g})$, which had the lowest root dry matter. Clone 7 recorded the largest leaf area $\left(2338 \mathrm{~cm}^{2}\right)$, significantly greater than that of the other clones, followed by Clones 1 and 3 , while Clone 8 recorded the lowest leaf area $\left(1511 \mathrm{~cm}^{2}\right)$, significantly lower than that of the Clones 7, 1 and 3 (Table 5). There was no significant difference in shoot dry matter, root dry matter or leaf area for the TE doses tested.

\section{DISCUSSION}

Plant growth is a result of the interaction between genetic and environmental factors, and refers to irreversible changes in the physical dimensions of plant organs such as mass, volume, length and area (Wilhelm \& McMaster 1995, Fagundes et al. 2007). Thus, due to the different genetic materials present in the clones, the Eucalyptus presented distinct growth characteristics. This fact may influence, for example, nutrient extraction capacity from the environment, resulting in clonal differences in competitive capacity, directly influencing plant architecture (Cruz et al. 2010, Graat et al. 2015, Colmanetti et al. 2017).

As an example of the different behaviors among genetic materials in relation to the allocation of photoassimilates, we discuss the growth performance of Clones 6 and 7. The former invested more in stem and root growth than in leaf production, resulting in higher values for shoot dry matter and root dry matter, with intermediate leaf area. Conversely, Clone 7 recorded a leaf area $26 \%$ higher than that of Clone 6, but not significantly different shoot dry matter and root dry matter (Table 5).

In addition, different responses of clones to stressors, such as water stress, were also observed in other studies (Costa e Silva et al. 2004, Valadares et al. 2014). In these conditions, the plants differed in their response to stomatal closure, which is related to the signalling of the abscisic acid hormone, being a direct result of the genetic material selected (Correia et al. 2014). In Eucalyptus, clonal differences also affect allocation speed of photoassimilates to the root (i.e., plant architecture), which leads to greater drought tolerance, by means of higher exploration capacity and soil penetration (Costa e Silva et al. 2004). The results obtained from studies that compared the response of Eucalyptus clones under different growth conditions may guide the selection of new materials to be tested in breeding programme (Vellini et al. 2008, Valadares et al. 2014, Colmanetti et al. 2017).

Since TE did not significantly influence the growth of the eight clones in our study, growth responses recorded are therefore attributed to clonal genetic differences (Tables 2, 4 and 5).

The positive effects of a low dose of a chemical compound that would be toxic at high doses, known as the hormetic effect (hormesis), was originally proposed by Southam and Erlich (1943). However, Belz and Duke (2014) point out that the occurrence of the hormetic phenomenon is influenced by several intrinsic and extrinsic characteristics to the plant's metabolism, such as climatic conditions that the plants are exposed after the application of the product (Belz \& Cedergreen 2010), cultivar or clone studied (McDonald et al. 2001, Bacha et al. 2017), the evaluation end point where hormesis is verified, i.e., a period of time after product application (Cedergreen et al. 2009) and the stage of development of the plant (Carvalho et al. 2013). This last factor may have been why the positive effects of TE application on Eucalyptus seedlings in our study were not observed, even while reported by previous studies (Pires et al. 2019, Correia \& Villela 2015, Bacha et al. 2019).

When treated with $30 \mathrm{~g}$ a.i. ha-1 $\mathrm{TE}$ before planting, Clone 5 seedlings showed a total dry mass gain that was $67 \%$ higher than the control, 90 days after planting (Bacha et al. 2017). The application of the same dose to Clone 5 seedlings 70 days after planting in the present study, however, showed no stimulatory effect on growth. Thus, to observe the beneficial effect of TE, we suggest that older plants need higher doses of the same product than do younger plants. The same was reported by Velini et al. (2008) for Commelina 
benghalensis treated with glyphosate where plants with 4 tillers needed five times more glyphosate than plants with 2 tillers to obtain similar shoot dry weight of about $42 \%$ when compared to nontreated plants.

Furthermore, when TE was applied at doses of 2 to $200 \mathrm{~g}$ a.i. ha ${ }^{-1}$ to E. urograndis (clone GG-100) seedlings at 46 days after planting, 100 and 200 a.i. ha ${ }^{-1}$ gave increases in crown diameter of $12 \%$ and $33 \%$, respectively, compared with the control (Correia \& Villela 2015). The results of that study showed that doses three and almost seven times higher than the one used in the present study (30 g a.i. $\mathrm{ha}^{-1}$ ) stimulated a $12 \%$ and $33 \%$ increase in crown diameter, respectively.

An optimal timing and rate of field applications can increase leaf area production (Pires et al. 2013, Correia \& Villela 2015, Bacha et al. 2018) and, ultimately, higher wood production from the increase in photosynthetically active area. Thus, the finding that older seedlings need higher doses compared to younger plants, may inform future studies examining the effect of TE on Eucalyptus in the context of productivity gains.

TE is an acylcyclohexanedione, which acts by inhibiting the final phases of gibberellin synthesis, due to the structural similarity between the chemical compound and 2-oxogluterate (Rademacher 2000, Rademacher 2016). The inhibition of hydroxylation of $\mathrm{GA}_{20}$ at the $3 \beta$-position by TE, interrupts the formation of $\mathrm{GA}_{1}$, which is one of the main biologically active gibberellins in the plant (Adams et al. 1992, Hedden 2016, Rademacher 2016). TE also inhibits the hydroxylation of $\mathrm{GA}_{1}$ at position $2 \beta$ (Griggs et al. 1991), which prevents it from transforming into $\mathrm{GA}_{8}$ (inactive gibberellin) (Hisamatsu et al. 1998). Maintaining GA $_{1}$ for a longer period in its bioactive conformation is possibly one of the causes for the beneficial effect provided by TE in Eucalyptus. We hypothesise that the accumulation of $\mathrm{GA}_{20}$, due to the inhibition of its conversion to $\mathrm{GA}_{1}$, may lead to overactive $\mathrm{GA}_{1}$ formation after degradation of the product by the plant.

The physiological processes that cause the stimulatory effect as a result of the application of TE have not yet been elucidated. Further research studying the effects of this plant growth regulator on Eucalyptus is needed, especially work that evaluates the hormonal changes in plants. Understanding this process can lead to increases in productivity.

Table 5 Shoot dry matter (SDM), roots dry matter (RDM) and leaf area of Eucalyptus clones at 42 days after application of trinexapac-ethyl

\begin{tabular}{lccc}
\hline Clones & SDM $(\mathrm{g})$ & RDM $(\mathrm{g})$ & Leaf area $\left(\mathrm{cm}^{2}\right)$ \\
\hline$(1)-3203$ & $19.77 \mathrm{abc}$ & $18.27 \mathrm{a}$ & $1978.08 \mathrm{~b}$ \\
$(2)-3487$ & $19.29 \mathrm{abc}$ & $16.27 \mathrm{ab}$ & $1643.43 \mathrm{bcd}$ \\
$(3)-$ I-144 & $17.58 \mathrm{bc}$ & $15.77 \mathrm{ab}$ & $1919.11 \mathrm{bc}$ \\
$(4)-3334$ & $17.33 \mathrm{c}$ & $15.24 \mathrm{~b}$ & $1618.65 \mathrm{~cd}$ \\
$(5)-1407$ & $19.22 \mathrm{abc}$ & $16.97 \mathrm{ab}$ & $1813.14 \mathrm{bcd}$ \\
$(6)-2361$ & $21.17 \mathrm{a}$ & $18.46 \mathrm{a}$ & $1850.18 \mathrm{bcd}$ \\
$(7)-$ I-224 & $20.10 \mathrm{ab}$ & $17.77 \mathrm{ab}$ & $2338.45 \mathrm{a}$ \\
$(8)-$ GG100 & $19.19 \mathrm{abc}$ & $16.84 \mathrm{ab}$ & $1511.34 \mathrm{~d}$ \\
\hline Trinexapac-ethyl & & & \\
\hline D1 $\left(15\right.$ g a.i. ha $\left.{ }^{-1}\right)$ & $19.94 \mathrm{a}$ & $17.69 \mathrm{a}$ & $1848.01 \mathrm{a}$ \\
D2 (30 g a.i. ha $\left.{ }^{-1}\right)$ & $18.84 \mathrm{a}$ & $16.38 \mathrm{a}$ & $1862.31 \mathrm{a}$ \\
D3 $\left(0\right.$ g a.i. ha $\left.{ }^{-1}\right)$ & $18.87 \mathrm{a}$ & $16.92 \mathrm{a}$ & $1791.82 \mathrm{a}$ \\
F clones $(\mathrm{C})$ & $4.10^{* *}$ & $3.07^{*}$ & $11.6^{* *}$ \\
F doses $(\mathrm{D})$ & $2.69^{\mathrm{ns}}$ & $2.75^{\mathrm{ns}}$ & $0.64^{\mathrm{ns}}$ \\
F C $\times$ D & $0.97^{\mathrm{ns}}$ & $0.92^{\mathrm{ns}}$ & $0.39^{\mathrm{ns}}$ \\
CV (\%) & 11.24 & 13.24 & 14.33 \\
\hline
\end{tabular}

Means followed by the same letter in the column do not differ from each other by Tukey's test at $5 \%$ probability; ${ }^{\text {ns }}=$ not significant; ${ }^{* *}=$ significant at $1 \%$ probability by the F-test; ${ }^{*}=$ significant at $5 \%$ probability by the F-tes; $\mathrm{CV}=$ coefficient of variation 


\section{CONCLUSION}

Eucalyptus clones differed in their growth regardless TE application. The chemical did not negatively affect any clone tested. However, the doses used here were not sufficient to cause a positive effect on Eucalyptus growth when applied at 70 days after planting. It is suggested that older Eucalyptus seedlings need higher doses of TE to show potential stimulatory effects on the growth of plants.

\section{REFERENCES}

Adams R, Kerber E, Pfister K et al. 1992. Studies on the action of the new growth retardant CGA 163'935 (Cimectacarb). Pp 818-827 in Karssen CM, van Loon LC, Vreugdenhil D (eds) Progress in plant growth regulation. Springer, Dordrecht.

Bacha AL, Martins PfRB, Alves PlCA et al. 2018. Trinexapac-ethyl causes stimulatory effect on Eucalyptus initial growth under nutritional deficiency. Canadian Journal of Forest Research 48: 94-100.

Bacha AL, Martins PFRB, Alves PLCA et al. 2019. Effect of trinexapac-ethyl, at two application timings, on the initial development of Eucalyptus under water deficit. Planta Daninha v37:e019176281.

Bacha AL, Martins PfRB, Carrega WC et al. 2017. Trinexapac-ethyl causes stimulatory effect on the initial growth of Eucalyptus urograndis clones. Journal of Agricultural Science 9: 189-197.

Barbosa JC \& Maldonado Júnior W. 2011. AgroEstat: sistema para análises estatísticas de ensaios agronômicos, versão 1.1.0.626. Jaboticabal: FCAV, Departamento de Ciências Exatas, Jaboticabal-SP.

Belz RG \& Cedergreen N. 2010. Parthenin hormesis in plants depends on growth conditions. Environmental and Experimental Botany 69: 293-301.

Belz RG \& Duke SO. 2014. Herbicides and plant hormesis. Pest Management Science 70: 698-707.

BENINCASA MMP. 2003. Análise de crescimento de plantas: noções básicas. Funep, Jaboticabal (SP).

Calabrese EJ \& Baldwin LA. 2002. Defining hormesis. Human E Experimental Toxicology 21: 91-97.

Carvalho LB, Alves PlCA \& Duke SO. 2013. Hormesis with glyphosate depends on coffee growth stage. Anais $d a$ Academia Brasileira de Ciências 85: 813-822.

Cedergreen N, Felby C, Porter Jr et al. 2009. Chemical stress can increase crop yield. Field Crop Research 114: 54-57.

Colmanetti MAA, Bacha AL, Braga AF et al. 2017. Interference of Urochloa decumbens and Panicum maximum in the initial growth of six clones of Eucalyptus urograndis. Australian Journal of Crop Science 11: 1261-1267.

Correia B, Pintó-Marijuan M, Neves L et al. 2014. Water stress and recovery in the performance of two Eucalyptus globulus clones: physiological and biochemical profiles. Physiologia Plantarum 150: 580-592.

Correia NM \& Villela GB. 2015. Trinexapac-ethyl and sulfometuron-methyl selectivity to young Eucalyptus plants. Planta Daninha 33: 259-266.
Costa E Silva F, Shvaleva a, Maroco JP et al. 2004. Responses to water stress in two Eucalyptus globulus clones differing in drought tolerance. Tree Physiology 24: 1165-1172.

Cruz MB, Alves PlCA, Karam D et Al. 2010. Capim-colonião e seus efeitos sobre o crescimento inicial de Clones de Eucalyptus $\times$ urograndis. Ciência Florestal 20: 391-401.

Fagundes JD, Santiago G, Mello AM et al. 2007. Crescimento, desenvolvimento e retardamento da senescência foliar em girassol de vaso (Helianthus annuus L.): fontes e doses de nitrogênio. Ciência Rural 37: 987-993.

Garau AM, Lemcoff JH, Ghersa CM et al. 2009. Weeds in Eucalyptus globulus subsp. maidenii (F. Muell) establishment: effects of competition on sapling growth and survivorship. New Forests 37: 251-264.

Garau AM, Lemcoff JH, Ghersa CM et al. 2008. Water stress tolerance in Eucalyptus globulus Labill. subsp. maidenii (F. Muell.) saplings induced by water restrictions imposed by weeds. Forest Ecology and Management 255: 2811-2819.

Graat Y, Rosa JO, Nepomuceno MP et al. 2015. Grass weeds interfering with eucalypt: effects of the distance of coexistence on the initial plant growth. Planta Daninha 33: 203-211.

Griggs DL, Hedden P, Temple-Smith Ke et al. 1991. Inhibition of gibberellin $2 \beta$-hydroxylases by acylcyclohexanedione derivatives. Phytochemistry 30: 2513-2517.

Hedden P. 2016. Gibberellin biosynthesis in higher plants. Pp 37-72 in Hedden P, Thomas SG (eds) Annual Plant Reviews. Volume 49: The Gibberellins. John Wiley \& Sons, Chichester.

Hisamatsu T, Koshioka M, Kubota S et al. 1998. Effect of gibberellin A4 and GA biosynthesis inhibitors on growth and flowering of stock (Matthiola incana (L.) $\mathrm{R}$. Br.). Journal of the Japanese Society for Horticultural Science 67: 537-543.

IBÁ - Indústria Brasileira de ÁRVOREs (BR). 2016. Relatório anual de 2016. http://iba.org/images/shared/ Biblioteca/IBA_RelatorioAnual2016_.pdf

Mcdonald L, Morgan T \& Jackson P. 2001. The effect of ripeners on the CCS of 47 sugarcane varieties in the Burdekin. Proceedings of the Australian Society of Sugar Cane Technologists 23: 102-108.

MODDUS ${ }^{\circledR}$. 2020. Bula. https://www.syngenta. com.br/sites/g/files/zhg256/f/moddus. pdf? token $=1511171921$

NAMBIAR EKS \& SANDS R. 1993. Competition for water and nutrients in forests. Canadian Journal of Forest Research 23: $1955-1968$.

Nascimento V, Arf O, Silva MG et al. 2009. Uso do regulador de crescimento etil-trinexapac em arroz de terras altas. Bragantia 68: 921-929.

Pereira FCM, Alves PLCA \& Martins JVF. 2013. Interference of grasses on the growth of Eucalyptus clones. Journal of Agricultural Science 5: 173-180.

Pereira FCM, Yamauti MS \& Alves PlCA. 2012. Interaction between weed management and covering fertilization in the initial growth of Eucalyptus grandis $\times$ E. urophylla. Revista Árvore 36: 941-950.

Pires RN, Pereira FCM, Nepomuceno MP et al. 2013. Effects of the simulated drift of ripeners on Eucalyptus urograndis. Journal of Agricultural Science 5: 78-86. 
Pires RN, Bacha AL, Nepomuceno MP et al. 2019. Can trinexapac-ethyl stimulate the initial growth of Eucalyptus? Ciência Florestal 29: 385-395.

Rademacher W. 2000. Growth retardants: effects on gibberellin biosynthesis and other metabolic pathways. Annual Review of Plant Physiology and Plant Molecular Biology 51: 501-531.

Rademacher W. 2016. Chemical regulators of gibberellin status and their application in plant production. Pp 359-403 in Hedden P, Thomas SG (eds) Annual Plant Reviews. Volume 49: The Gibberellins. John Wiley \& Sons, Chichester.

Retief ECL \& Stanger TK. 2009. Genetic control of wood density and bark thickness, and their correlations with diameter, in pure and hybrid populations of Eucalyptus grandis and E. urophylla in South Africa. Southern Forests 71: 147-153.

Sankaran KV, Chacko KC, Pandalai RC et al. 2004. Influence of harvest residue management, weed management, legume cover cropping and soil trenching on Eucalyptus productivity in Kerala, India. Journal of Tropical Forest Science 16: 232-247.
Southam CM \& ERLich J. 1943. Effects of extract of western red-cedar heartwood on certain wood-decaying fungi in culture. Phytopathology 33: 517-524.

Stape JL, Binkley D, Ryan MG et al. 2004. Water use, water limitation, and water use efficiency in a Eucalyptus plantation. Bosque 25: 35-41.

Valadares J, Paula NF \& Paula RC. 2014. Physiological changes in Eucalyptus hybrids under different irrigation regimes. Revista Ciência Agronômica 45: 805-814.

Velini ED, Alves E, Godoy MC et Al. 2008. Glyphosate applied at low doses can stimulate plant growth. Pest Management Science 64: 489-496.

Vellini Altt, Paula NF, Alves PlCA et al. 2008. Respostas fisiológicas de diferentes Clones de eucalipto sob diferentes regimes de irrigação. Revista Árvore 32: 651-663.

Wilhelm WW \& Mcmaster GS. 1995. Importance of the phyllochron in studying development and growth in grasses. Crop Science 35: 1-3. 